\title{
CHANGES IN CULTURAL ATTITUDES AND BELIEFS OF FEMALE UNIVERSITY STUDENTS IN THE UNITED ARAB EMIRATES
}

\author{
Nancy Sonleitner, PhD \\ University of Tennessee Martin, USA \\ Deborah Wooldridge, PhD \\ Bowling Green State University, USA
}

\begin{abstract}
Until recently college education for women in the United Arab Emirates was not considered to be an important investment, since girls were expected to stop schooling after graduation from high school, get married, and begin a family. Since becoming a nation in the past 30 plus years, however, the Emirati government has been working to ensure that all Emirates are educated through elementary school, and have launched a program to provide Emirati women a college education. While the recognized function of education is to provide information about the world, one unintentional result is that attitudes are liberalized. This study examines 104 Emirate female college students' perceptions of changes in attitudes, and expectations for their futures. A questionnaire was developed specifically for the study. Results show that attitudes about family relationships and friendships are undergoing change, as well as expectations for future employment.
\end{abstract}

Keywords: Culture, attitudes, beliefs, higher education, change

\section{Introduction}

Rapid shifts in national development from a traditional to postindustrial society affect cultural attitudes and beliefs (Inglehart \& Baker, 2000) and the sense that one belongs to a particular cultural group (Dhaouadi, 2002). Changes in cultural identity and corresponding attitudes and beliefs are complex and influenced by different factors, one of the most important of which is modernization (Goode, 1963; Hitlin, 2003). Several studies have found associations between modernization and changes in cultural identity, and have identified factors of modernization that affect cultural identity such as education, and media (Khalaf and Alkobaisi, 1999; 
Thompson, 1999; Esposito, 2003; Schvaneveldt, Kerpelman, \& Schvaneveldt, 2005).

This research examined university women's educational experiences as they are related to changing attitudes and beliefs. Specifically, the study examines the relationship between gaining an education at the college level, and expectations for future plans, attitudes towards relationships with parents, and exposure to non-western media and western media.

\section{Review of Literature}

In the past thirty plus years, the United Arab Emirates (UAE) has undergone socio-economic and political transformations (Findlow, 2000) associated with modernization. One factor strongly affecting cultural attitudes and beliefs of United Arab Emirates females is education and work. In the past, Emirati women's education was limited. However, since the early 1970s, the United Arab Emirates has made great advances in modernizing its educational system, giving women opportunities to achieve a high school diploma, and attend colleges and universities (Heckman, 2000; Ministry of Information and Culture, 2014). From the onset, the UAE constitution was formulated to safeguard the rights of women by providing them equal opportunities. Women therefore have the same legal status, claim to property, access to education, and the right to practice any profession (Halloran, 1999; Ministry of Information and Culture, 2014). With an increasing trend in mothers being in the workforce there appears to be a supporting shift in values. (Abdel-Rauf, 2000).

By completing their education, more Emirati women are asserting their intentions to enter the labor force and choose their futures (Crabtree, 2007; Schvaneveldt, Kerpelman, \& Schvaneveldt, 2005). Women's education and participation in paid work are overcoming barriers to traditional roles and activities for women and are bringing new cultural attitudes and beliefs (Ministry of Economy, 2007; Ministry of Information and Culture, 2014; Devriese, 2008; Crabtree, 2007; Schvaneveldt, et al., 2005). Crabtree's (2007), analysis of in-depth interviews with Emirati mothers and daughters found that the young women are expecting to work outside the home, and this expectation is shared by the mothers. UAE parents recognize the importance of the availability of educational opportunities provided by the government. Some progressive Emirati national parents encourage their children to adopt modern ideas within the limits of religion. Conversely, conservative parents tend to not accept modern changes within the culture and often have more control over their children's activities, including dress, associations with friends, and choice of a suitable subject to study in school (Inglehart \& Baker, 2000). Madsen (2010) found that UAE 
professional female leaders had open minded fathers, strong higher education and strated reading books as a yound child.

Along with education and work, media are important agents of cultural identity formation (Jendli \& Khelifa, 2004). Exposure to foreign media may influence Emirati women's ideas, attitudes, and behavior. Women may mimic media role model images of assertiveness and expectations of equality with men. Media may influence people, especially women, to advocate for human rights and to call for changes in society (DeVriese, 2008). Historically, Emirati women did not work outside their homes. However, in recent years women have begun working in jobs that are viewed as "women's jobs" and include teaching and school counselor at girls' schools. With the influence of modernization, including education and media images of women's possibilities, women have sought employment in private and public sectors including multinational companies where they work and compete with men ( Al-Ali, 2008).

Traditional values of family and obedience to parental authority (Inglehart \& Baker, 2000) are changing and Emirati youth are beginning to identify themselves as individuals, to seek what is best for them, and they are beginning to change the long held traditions associated with belonging to an extended family group and conforming to the advice and demands of family authorities. One example of this change is the establishment of nuclear families when couples marry. Historically, couples would reside with the husbands' families rather than begin married life on their own (Citizenship and Immigration, nd). This new practice disrupts family cohesiveness and intimacy. Traditionally, women were not allowed to exit the home compound without being accompanied by a male relative, even if that relative was a young son. This traditional practice is changing, and women are allowed to venture outside the home with female relatives. Additionally, as the young women attend college, they are forging friendships with non-related women, and are expanding their relationships to include expatriates, including expatriate male teachers.

\section{Methodology}

This research was conducted at a government supported university for Emirati national females, where instruction is in English. Initially, the university was designed to educate Emirati women, who, because of travel constraints, could not attend universities abroad. In recent years the university has opened it's doors to international students and to males. There are campuses located in Abu Dhabi and Dubai. Student's can earn Bachelor's or Master's degrees.

To investigate changes in cultural attitudes and beliefs 104 female students between the ages of 17 to 36 years of age (mean age 20 years) from 
a UAE University completed an online questionnaire in English. Survey items included demographic data of age, which emirate they grew up in, whether they attended public or private school prior to entering the university, family income ranging from low to very high, marital status, current classification ranging from $1^{\text {st }}$ year English language readiness (and thus to have just begun their education) to $2^{\text {nd }}$ year in the major (and therefore likely to graduate in that year). Students were asked about their parents' ages, which country their mother was from, parents' educational level, and in which country their parents were educated. To measure change in cultural beliefs and practices students were asked about their appearance preferences in public, their perceptions of personal autonomy and independence, and exposure to and influence of media.

\section{Results}

Less than half the students (41.4\%) grew up in the progressive and liberal Emirate of Dubai, and about the same percent grew up in the large, but more conservative Emirate of Abu Dhabi (44.2\%). The remaining 11\% grew up in smaller, traditional and conservative emirates, and 3\% grew up outside the UAE. Over half (58.8\%) attended public school before entering the university and $41.2 \%$ had attended private school. Ninety-two percent were never married, $3.9 \%$ married, and $3.9 \%$ separated, divorced or widowed. Nearly nine percent (8.8\%) were in the readiness program, $47.6 \%$ were in general education (first 2 years of their education after English readiness), and $44.1 \%$ were in first or second year of their major. No students reported their family income was low, 53.4\% said their family income was average, $37.9 \%$ said it was high, and $8.7 \%$ said it was very high.

Parental age could be a factor in non-traditional cultural values and beliefs with younger parents establishing a more liberal home environment. Parents' ages ranged between 30 and 57 for mothers and 39 to 70 for father, with mean maternal age of 46.1 and mean paternal age of 54.8. Maternal origin may be associated with cultural values and beliefs. Mothers from more modernized countries may impart their orientation to their children. This may also signify a more modern orientation of fathers as well. Eightytwo percent of mothers were Emirati, 8\% originated in other Gulf nations, $6 \%$ in other Arab countries, and $4 \%$ originated from Iran or India. All fathers originated from the UAE.

Educational attainment is associated with liberal outlooks and may be brought into the home environment. Ten percent (10.8\%) of fathers were unschooled, 36.9\% had achieved primary school only or had graduated from high school, and $52.4 \%$ had either some college or graduated with a bachelor or graduate degree. Among mothers, $12.6 \%$ had no education, $56.3 \%$ had 
attended only primary school or had graduated from high school, and 31.1\% had attended or graduated from college with a bachelor or graduate degree.

Country of receiving one's education may influence traditional cultural attitudes and beliefs because those educated in Western countries were exposed to the progressive and democratic social orientations of their host countries. Among fathers who had attended school, 54.8\% were educated in the UAE, $4.4 \%$ received their education in another gulf country, $25.3 \%$ in the U.S., the U.K. or Europe, $14.3 \%$ in other Arab countries, and $2.2 \%$ were unspecified other countries. Among mothers who were educated, $65.7 \%$ were educated in the UAE, $10.8 \%$ were educated in other Gulf countries, 3.9\% had been educated in other Arab countries, $2.9 \%$ had been educated in Iran or India, and 3.9\% received their education in the U.S. or U.K.

In describing their home environment, over half of the students (55.5\%) said it was modern or very modern, and 38\% said their relationship with their fathers was open or very open, whereas $50 \%$ said their relationship was not too traditional or too open. Brothers, whether younger or older, have as much authority over their sisters as fathers. Sixty percent of students described their relationship with their brother as open or very open. Two thirds (64\%) said their relationship with their mother was open or very open.

Students were asked about their autonomy in deciding their future because of their education. Nearly all students (95.1\%) said because of their education they would decide if they work and $96.0 \%$ said they would decide where they will work. However, 73.0\% said they would decide if they will work in a work setting with men, and the remaining one quarter of the students leaving that decision to their families. Nearly half (45.5\%) agreed with the statement that because of their education they decide who their friends are, and $54.5 \%$ agreed that because of their education they decide when they see their friends. This finding illustrates the transitional process of these students' autonomy. Nearly three quarters of students (70.4\%) agreed that because of their education they would decide who they would marry. Overall, $90 \%$ said that because of their education, in general they decide for themselves. This finding suggests that while the students expect family influence in some aspects of decisions about their lives, in general they believe they have the autonomy to control their lives.

In modernized societies women typically delay marriage and childbearing until after they finish their education and get their career started. Traditionally among the UAE nationals marriage typically occurs when a young woman under the age of 25 and the first child is born within the first year of marriage. Among non-married students in the sample, $54.4 \%$ said they would not marry until after they graduated from the university, and $29.4 \%$ said they would marry after they got started in their career. Among 
students who did not have children at the time, 53.2\% said they would have babies after they graduated, and $40.4 \%$ said they would have babies after they got started in their career.

It appears that the students in this study have more liberal or progressive relationships with their parents and brothers than traditionally expected, as changes were reported in relationships with fathers, brothers and mothers. Emirati families are extended and close-knit. Daughters traditionally are close with the other females in the family, while fathers and brothers traditionally wield strict control over the females. Families typically do not socialize with non-family, and spend much of their work and leisure time in the company of family. It is notable that nearly half (45.5\%) of students assert that their education enables them to decide who their friends are and over half (54.5\%) said they decide when they see their friends. Use of cell phones and internet access may contribute to social connections outside the extended family. Also of note is the finding that one third (35\%) of students said they speak English more than Arabic with their friends. Using English conversationally with friends suggests further cultural change.

Just over half of fathers had attended or graduated from college with one fourth of them having been educated in the US, UK, or Europe where ideas, behaviors, and values are generally more liberal compared with the UAE, suggesting that the home environment may be influenced by paternal foreign experiences.

Access to the media may also be influencing cultural changes. About half the students said they thought they were influenced by Western media (47.4\%) and in a separate question about half (42.9\%) said they thought they were influenced by Westernized Arabic media. This influence is experienced through satellite TV, radio, internet, and print media. Examples students provided of how they were being influenced included food choices, the way they dress, being more outspoken and creative, being more open and accepting of others and being open-minded. Students also said they were influenced in their knowledge about other cultures and global events.

\section{Conclusion}

Access to education and the various forms of media, coupled with elements of their home environment appears to impact female students at Zayed University, the Emirati national university in the United Arab Emirates that has a mission of educating Emirati women. The women in the study may be in the initial stages of departing from traditionally held cultural attitudes, values, and beliefs. The findings from this study indicate that the majority of female students' cultural perspectives are evolving from the more socially isolated and subordinate role that, until recently, was the dominant 
way of life for Emirati females. The UAE federal government's position on the role of women asserts that women are expected to take their place in the development of the country, and that they are to be educated and engage in paid work. These social realities have implications for delaying marriage and childbearing as women enter colleges and universities and move into careers after graduation. The majority of students believed that their education provided them with a sense of autonomy and independence and they believe they have control over their futures, including when and with whom they would marry, and the timing of childbearing. They also expect to decide if they will work, as well as conditions of the working environment.

With these emerging changes in cultural practices, beliefs and values the UAE will continue to modernize. The female students of this study will integrate new cultural practices into their traditional Emirati culture, and most likely each new cohort of female college students will continue to expect to enter the professional force work and make decisions about how their lives will be. In the transition period between traditional and modern and being caught between old and new, the students in this study still wanted to get married, have babies and develop a career. As with women in the West they, too, will learn how to balance work and family. Although the mainstream culture lags behind in changing attitudes, beliefs, values and practices, a new generation of female college graduates expects changes are happening, and they will instill these new cultural ideas into their children.

\section{References:}

Abdel-Rauf, M. (2000). The Islamic view of women and the family. AlSaadawi Publications, Alexandria, VA.

Al-Ali, J. (2008). Emiratisation: Drawing UAE nationals into their surging economy. The Internaional Journal of Sociology and Social Policy, 28(9/10): 365-379.

Citizenship and Immigration Canada (nd). United Arab Emirates - Family

Life, retrieved from http://www.cp-pc.ca/English/uae/family.html

Crabtree, S.A. (2007). Culture, Gender and the Influence of Social Change amongstEmirate Families in the United Arab Emirates. Journal of

Comparative Family Studies, 38(4): 575-587.

Devriese, L. (2008). Renegotiating Feminist Praxis in the Arabian Gulf.

Cultural Dynamics 20(1):73-94.

Dhaouadi, M. (2002). Globalization of the other underdevelopment: Third world cultural identities. Kuala Lumpur: Noodeen.

Esposito, J. L. (2003). The Position of Women in Islam, Gulf News, August 8, 2003, retrieved from

http://archive.gulfnews.com/articles/03/08/22/95794.html 
Findlow, S. (2000). The United Arab Emirates: Nationalism and Arab Islamic Identity. Abu Dhabi: The Emirates Center for Strategic Studies and Research.

Goode, W. J. (1963). World Revolutions and Family Patterns. New York: The Free Press.

Halloran, F. W. (1999). Zayed University: A new model for higher education in the United Arab Emirates. In Emirates Center for Strategic Studies and Research (Eds.), Education in the Arab World: Challenges for the new millennium. (pp.323-330). Abu Dhabi: Emirates Center for Strategic Studies and Research.

Heckman, J. J. (2000). Policies to foster human capital. Research in Economics,54(1), 3-56.

Hitlin, S. (2003). Values as the core personal identity: Drawing links between two theories of self-image. Social Psychology Quarterly, 66, 118. Inglehart, R. \& Baker, W. (2000). Modernization, Cultural Change, and the Persistence of Traditional Values. American Sociological Review, 65:19 51.

Jendli, A., \& Khelifa, M. (2004). Effects of Western-Style Arabic Music Video Clips on Emirati Youth Identity and Culture. Paper presented at the Arab Satellites in a Changing World. Cairo, Egypt.

Khalaf, S., \& Alkobaisi S. (1999). Migrants' strategies in the oil-rich gulf societies. British Journal of Middle Eastern Studies, 26:273.

Madsen, S. R.(2010). The Experiences of UAE Women Leaders in Developing Leadership Early in Life. Feminist Formations, 22(3): 75-75-95. Ministry of Economy. (2007). Millennium Development Goals-United Arab Emirates Report. Abu Dhabi: United Nations Development Program. Ministry of Information and Culture (2014). United Arab Emirates Yearbook 2013. London: Trident Press.

Schvaneveldt, P.L., Kerpelman, J., \& Schvaneveldt, J.D. (2005).

Generational and Cultural Changes in Family Life in the United Arab Emirates: A Comparison of Mothers and Daughters. Journal of Comparative Family Studies, 36 (1): 77-91.

Thompson, J. (1999). Globalization and Culture. Cambridge: Polity Press. European Journal of Educational Sciences, EJCEM 2014 